\title{
WELCOME TO VOLUME 35
}

\section{Colin Hendrie}

Editor in Chief

Welcome to Volume 35 of Human Ethology, the official peer-reviewed journal of the International Society for Human Ethology (ISHE). Twenty-twenty sees the journal move into its sixth decade of publication and the main focus remains on studies relating to the direct observation of human behaviour or that of closely related species. To take advantage of the flexibility of the on-line format contributions are published as they are accepted throughout the year. Research articles, review articles, book reviews and a variety of other contributions including studies relating to replication issues are all welcomed. There is also now a supplement for abstracts submitted for presentation at ISHE meetings, which this year is to be held in Liverpool (July $6^{\text {th }}-10^{\text {th }} 2020$ ). Full papers intended for publication in Human Ethology are submitted via ScholarOne and given their own DOI link once accepted, so are easily accessed through Crossref and other indexing sites.

Human Ethology has a 2019 impact factor of 1.631 (1.463 in 2018) and is completely open access, free for authors to publish in and free for readers to read. 